\title{
Antibacterial Activity of Human Neutrophil Defensins in Experimental Infections in Mice Is Accompanied by Increased Leukocyte Accumulation
}

\author{
Mick M. Welling, ${ }^{\star}$ Pieter S. Hiemstra, ${ }^{\ddagger}$ Maria Th. van den Barselaar, ${ }^{\S}$ Akke Paulusma-Annema, ${ }^{\S}$ Peter H. Nibbering, ${ }^{\S}$ \\ Ernest K.J. Pauwels, ${ }^{*}$ and Wim Calame*\| \\ *Department of Radiology, Division of Nuclear Medicine, ${ }^{\ddagger}$ Department of Pulmonology, and ${ }^{\S}$ Department of Infectious Diseases, Leiden \\ University Medical Center, Leiden, The Netherlands; and ${ }^{\|}$Hercules European Research Center, Barneveld, The Netherlands
}

\begin{abstract}
Neutrophil defensins (or human neutrophil peptides-HNP) are major constituents of the azurophilic granules of human neutrophils and have been shown to display broad-spectrum antimicrobial activity. Other activities of these defensins, which are released from stimulated neutrophils, include cytotoxic, stimulatory, and chemotactic activities toward a variety of target cells. We studied the potential use of HNP-1 for antibacterial therapy of experimental bacterial infections in mice. In experimental peritoneal Klebsiella pneumoniae infections in mice, HNP-1 injection was shown to markedly reduce bacterial numbers in the infected peritoneal cavity $24 \mathrm{~h}$ after infection. This antibacterial effect was found to be associated with an increased influx of macrophages, granulocytes, and lymphocytes into the peritoneal cavity. These leukocytes appeared to be a requirement for the antibacterial effect, since in leukocytopenic mice administration of HNP-1 did not display antibacterial activity. HNP-1 treatment also reduced bacterial numbers in experimental K. pneumoniae or Staphylococcus aureus thigh muscle infections. In this model, radiolabeled HNP-1 was found to accumulate at the site of infection, whereas most of the injected HNP-1 was rapidly removed from the circulation via renal excretion. These results demonstrate that neutrophil defensins display marked in vivo antibacterial activity in experimental infections in mice and that this activity appears to be mediated, at least in part, by local leukocyte accumulation. (J. Clin. Invest. 1998. 102:1583-1590.) Key words: infection • defensins • antibacterial activity • leukocytes $\cdot$ chemotaxis
\end{abstract}

\section{Introduction}

In view of the increased bacterial resistance to conventional antibiotics, the study of endogenous antimicrobial peptides may lead to the development of new drugs for the treatment of infections (1). These peptides play an important role in the in-

\footnotetext{
Address correspondence to Dr. M.M. Welling, Department of Radiology, Division of Nuclear Medicine, Leiden University Medical Center, C4-Q, P.O. Box 9600, NL-2300 RC Leiden, The Netherlands. Phone: 31-71-526-3475; FAX: 31-71-526-6751; E-mail: welling@rullf2. medfac.leidenuniv.nl

Received for publication 8 April 1998 and accepted in revised form 25 August 1998.
}

The Journal of Clinical Investigation

Volume 102, Number 8, October 1998, 1583-1590

http://www.jci.org nate host defense against infections in a wide variety of organisms. Human neutrophil defensins (human neutrophil peptide [HNP]-1, $-2,-3$, and -4$)^{1}$ are antimicrobial peptides that are stored in the granules of neutrophils and they are transferred to the phagolysosome upon phagocytosis. In vitro, these peptides kill a variety of bacteria, including Staphylococcus aureus, Pseudomonas aeruginosa, and Escherichia coli, many fungi, and some enveloped viruses (2-4). In addition to their antimicrobial activity, defensins also display cytotoxic activity toward various eukaryotic cells and cell lines (4). Thus, when released from stimulated neutrophils, defensins may contribute to tissue injury. Various other extracellular activities of defensins have been described (4). These activities include chemotactic activity for monocytes and lymphocytes $(5,6)$ and the ability to stimulate IL-8 synthesis in airway epithelial cells (7).

The aim of the present study was to investigate the in vivo antibacterial activity of the human neutrophil defensin HNP-1 in experimental peritoneal and thigh muscle bacterial infections. Simultaneously, to explore possible modes of action, the effect of HNP-1 on peritoneal leukocyte numbers was determined to investigate whether the antibacterial activity of HNP-1 was accompanied by leukocyte accumulation (8). In addition, to study accumulation of HNP-1 at the site of infection and its biodistribution in various organs, ${ }^{99 \mathrm{~m}}$ Technetium ( $\left.{ }^{99 \mathrm{~m}} \mathrm{Tc}\right)$-labeled HNP-1 was used in experimental Klebsiella pneumoniae (gram-negative) or $S$. aureus (gram-positive) thigh infections. These results were compared with those obtained using ${ }^{99 \mathrm{~m}} \mathrm{Tc}-\mathrm{IgG}$, an established marker for infection $(9,10)$.

\section{Methods}

Proteins. Human neutrophil defensin HNP-1 was purified from human neutrophils as described (7). Briefly, neutrophils were isolated from enriched leukocyte preparations, obtained from the Bloodbank of the Leiden University Medical Center. Next, purified neutrophils were disrupted by nitrogen cavitation, cellular debris was removed by centrifugation for $10 \mathrm{~min}$ at $540 \mathrm{~g}$ at $4^{\circ} \mathrm{C}$, and the resulting supernatant was centrifuged for $20 \mathrm{~min}$ at $27,000 \mathrm{~g}$ at $4^{\circ} \mathrm{C}$ to sediment granules. Granule proteins were extracted from this fraction using $5 \%$ (vol/vol) acetic acid and fractionated by gel filtration on a Sephacryl S-200 HR column $(2.5 \times 100 \mathrm{~cm}$; Pharmacia, Uppsala, Sweden $)$ in $5 \%(\mathrm{vol} / \mathrm{vol})$ acetic acid. The fractions containing HNP-1 were further purified by reverse-phase HPLC on a C18 column $(4.6 \times 250$ $\mathrm{mm}$; Vydac, The Separations Group, Hesperia, CA) using a linear water-acetonitrile gradient that contained $0.1 \%$ trifluoroacetic acid as an ion-pairing agent. The purity of the defensin preparation was as-

1. Abbreviations used in this paper: ${ }^{99 \mathrm{~m}} \mathrm{Tc},{ }^{99 \mathrm{~m}}$ Technetium; HAc, $0.01 \mathrm{M}$ acetic acid, pH 4; HNP, human neutrophil peptide; Na-PB, $10 \mathrm{mM}$ sodium phosphate buffer, $\mathrm{pH}$ 7.4; ROI, region of interest; T/NT, target-to-nontarget ratio. 
sessed by SDS-PAGE, acid urea-PAGE, and laser desorption mass spectrometry. The LPS content of the HNP-1 preparation at $100 \mu \mathrm{g} /$ $\mathrm{ml}$ was lower than $100 \mathrm{pg} / \mathrm{ml}$ by the Limulus assay (Chromogenix, Mölndal, Sweden). Purified pyrogen-free polyclonal human IgG was obtained from the Central Laboratory of the Red Cross Blood Transfusion Service (CLB, Amsterdam, The Netherlands).

Reduction and alkylation of HNP-1. For selected control experiments, HNP-1 was used that had been denaturated by reduction and alkylation of the disulphide bonds as described by Daher et al. (11). Briefly, HNP-1 was dissolved to a concentration of $1 \mathrm{mg}$ of peptide/ $\mathrm{ml}$ in $10 \mathrm{mM}$ sodium phosphate buffer, $\mathrm{pH} 7.4$ (Na-PB). To reduce disulphide bonds into free cysteine thiols, $25 \mu \mathrm{l}$ of the HNP-1 solution was mixed with $50 \mu \mathrm{l}$ of a $1.5 \mathrm{mg}$ DTT (Sigma Chemical Company, St. Louis, MO)/ml Na-PB solution. This mixture was incubated for $4 \mathrm{~h}$ at $50^{\circ} \mathrm{C}$ under nitrogen to prevent spontaneous reoxidation. To irreversibly block reoxidation of the free cysteines, $0.1 \mathrm{ml}$ of an iodoacetamide (Sigma Chemical Co.) solution of $0.1 \mathrm{mg} / \mathrm{ml}$ was added to the mixture and incubated for $20 \mathrm{~min}$ at room temperature in the dark. To remove an excess of reactants, the mixture was diluted to $1 \mathrm{ml}$ with $0.01 \mathrm{M}$ acetic acid, $\mathrm{pH} 4$ (HAc) and applied to a Sep-Pak C-18 cartridge (Waters, Milford, MA), previously flushed with $20 \mathrm{ml}$ of $0.01 \mathrm{M} \mathrm{HAc}$. After rinsing with $20 \mathrm{ml}$ of $0.01 \mathrm{M} \mathrm{HAc}$, HNP-1 was eluted with $2 \mathrm{ml}$ of methanol (Sigma Chemical Co.), followed by evaporating methanol using hot air. HNP-1 was resuspended in $100 \mu \mathrm{l}$ of Na-PB, and the peptide content was determined with the bicinchoninic acid method (Pierce, Oud-Beijerland, The Netherlands).

Labeling procedure and quality control. To study the pharmacokinetics of this antimicrobial peptide in vivo, HNP-1 was labeled with ${ }^{99 \mathrm{~m}} \mathrm{Tc}$ as previously described $(12,13)$. Briefly, $10 \mu \mathrm{l}$ of HNP-1 $(1 \mathrm{mg} /$ $\mathrm{ml}$ of $10 \mathrm{mM} \mathrm{Na}-\mathrm{PB}, \mathrm{pH} 3.0$ ) was added to $2 \mu \mathrm{l}$ of an aseptical solution containing $0.5 \mathrm{mg} / \mathrm{ml}$ of stannous pyrophosphate (Department of Clinical Pharmacy and Toxicology, Leiden University Medical Center, Leiden, The Netherlands). Immediately thereafter, $4 \mu \mathrm{l}$ of a solution containing $10 \mathrm{mg}$ of $\mathrm{KBH}_{4}$ (crystalline; Sigma Chemical Co.)/ml $0.1 \mathrm{M}$ of $\mathrm{NaOH}$ was added. After addition of $0.1 \mathrm{ml}$ of ${ }^{99 \mathrm{~m}} \mathrm{Tc}$-sodium pertechnetate solution (20 MBq; Mallinckrodt Medical BV, Petten, The Netherlands), the mixture was gently stirred at room temperature for $30 \mathrm{~min}$. To remove an excess of reactants, the mixture was applied to and eluted from a Sep-Pak C-18 cartridge as described above. In vivo activity and biodistribution of ${ }^{99 \mathrm{~m}} \mathrm{Tc}$-labeled HNP-1 were compared with those of ${ }^{99 \mathrm{~m}} \mathrm{Tc}-$ labeled $\mathrm{IgG}$, a well established marker for monitoring infections $(14,15)$. Labeling yields of ${ }^{99 \mathrm{~m}} \mathrm{Tc}-$ labeled HNP-1 and IgG assessed by Sep-Pak analysis amounted to $88 \%$ and $90 \%$, respectively. In addition, reverse-phase HPLC profiles of unlabeled, ${ }^{99 \mathrm{~m}} \mathrm{Tc}-1 \mathrm{abeled}$, and reduced and alkylated HNP-1 revealed that the latter eluted faster from the column than the other two, indicating that reduced and alkylated HNP-1, but not ${ }^{99 \mathrm{~m}} \mathrm{Tc}-$ labeled peptide, differed from native HNP-1.

Bacteria. K. pneumoniae ATCC 43816 and S. aureus ATCC 25923 were obtained from the American Type Culture Collection (Rockville, MD). Overnight cultures of these bacteria were prepared in brain heart infusion broth (Oxoid, Basingstoke, UK) in a shaking waterbath at $37^{\circ} \mathrm{C}$. Aliquots of suspensions containing about $10^{9}$ viable bacteria per milliliter of brain heart infusion broth were snap-frozen in liquid nitrogen and stored at $-70^{\circ} \mathrm{C}$. Just before use, an aliquot of this suspension was rapidly thawed in a waterbath at $37^{\circ} \mathrm{C}$ and diluted in pyrogen-free saline.

Mice. Animal studies were done in compliance with the relevant laws relating to the conduct of animal experiments. Specific pathogen-free male Swiss mice weighing 20-25 g (Broekman Institute, Someren, The Netherlands) were used throughout the study. Mice were housed in the central animal housing facilities for at least $1 \mathrm{wk}$ before the onset of the experiments. Food and water were given ad libitum.

Experimental peritoneal infections. To study the effect of infection with purified HNP-1 on bacterial infections in vivo, an experimental peritoneal infection model in mice was used (16). Mice were anesthetized with an intraperitoneal injection of $0.2 \mathrm{ml}$ of saline con- taining $1 \mathrm{mg}$ of fluanisone and $0.03 \mathrm{mg}$ of fentanyl citrate (Hypnorm; Janssen Pharmaceutics, Tilburg, The Netherlands). Immediately thereafter, an experimental intraperitoneal infection was established by injection of $1 \times 10^{6} \mathrm{CFUs}$ of $K$. pneumoniae in $0.1 \mathrm{ml}$ of saline into the peritoneal cavity. $5 \mathrm{~min}$ thereafter, $0.2 \mathrm{ml}$ of saline, containing various concentrations of HNP-1 (range $4 \mathrm{ng}$ to $4 \mu \mathrm{g} / 0.2 \mathrm{ml}$ ) or saline alone, was injected intravenously. Additional experiments were performed with $4 \mu \mathrm{g}$ of denaturated HNP-1. At various intervals, ranging between 0-24 h after injection of HNP-1, the mice were sacrificed by an intraperitoneal injection of $0.25 \mathrm{ml}$ of saline containing $12 \mathrm{mg}$ of sodium pentobarbital. Subsequently, the peritoneal cavity was lavaged by intraperitoneal injection of $4 \mathrm{ml}$ of ice-cold PBS supplemented with heparin $(50 \mathrm{IE} / \mathrm{ml}$; Leo Pharmaceutical Products BV, Weesp, The Netherlands). The abdomen was gently shaken for $60 \mathrm{~s}$, whereafter the peritoneal cells and bacteria were harvested and centrifuged for $5 \mathrm{~min}$ at $110 \mathrm{~g}$ at $4^{\circ} \mathrm{C}$. The number of bacteria (as assessed via CFUs) in the supernatant was determined by plating serial dilutions on diagnostic sensitivity test agar plates (Oxoid). The pellet containing the leukocytes was resuspended in $1 \mathrm{ml}$ of PBS, and the total number of peritoneal leukocytes was counted in a Bürker hemocytometer after staining with a $0.2 \%$ Türks solution. The percentage of peritoneal macrophages, lymphocytes, and granulocytes was calculated by differential counts of 100 leukocytes, made in two MayGrünwald Giemsa-stained cytospin preparations $(5 \mathrm{~min} \times 110 \mathrm{~g})$.

To study a possible role of leukocytes in the in vivo antibacterial effects of HNP-1, similar experiments were performed in mice rendered leukocytopenic by a single subcutaneous injection of $200 \mathrm{mg} / \mathrm{kg}$ of cyclophosphamide (Endoxan-Asta; Dogra, Diemen, The Netherlands), $4 \mathrm{~d}$ before the onset of the experiments (17).

Experimental thigh infections. In addition to the peritoneal infection model, an experimental thigh infection model was used to assess the effect of HNP-1 treatment on bacterial numbers and to analyze simultaneously the accumulation of ${ }^{99 \mathrm{~m}} \mathrm{Tc}$-labeled HNP-1 in the infected areas using scintigraphic techniques. Mice were anesthetized with an intraperitoneal injection of $0.2 \mathrm{ml}$ of saline containing $1 \mathrm{mg}$ of fluanisone and $0.03 \mathrm{mg}$ of fentanyl citrate (Hypnorm; Janssen Pharmaceutics). Immediately thereafter, $2 \times 10^{5} \mathrm{CFUs}$ of $\mathrm{K}$. pneumoniae or $S$. aureus in $0.1 \mathrm{ml}$ of saline were injected into the right thigh muscle $(9,18) .5 \mathrm{~min}$ or $24 \mathrm{~h}$ thereafter, $0.2 \mathrm{ml}$ containing $0.4 \mu \mathrm{g}$ of ${ }^{99 \mathrm{~m}} \mathrm{Tc}-$ labeled HNP-1 $(0.58 \mu \mathrm{M})$ was injected intraperitoneally. As controls, $0.2 \mathrm{ml}$ containing $0.4 \mu \mathrm{g}$ of unlabeled HNP-1, $10 \mu \mathrm{g}$ of ${ }^{99 \mathrm{~m}} \mathrm{Tc}$-labeled IgG $(0.33 \mu \mathrm{M})$, or saline alone was administered. At the end of the experiments $(4 \mathrm{~h}$ or $24 \mathrm{~h}$ after injection of the tracers), the animals were sacrificed by an intraperitoneal injection of $0.25 \mathrm{ml}$ of saline containing $12 \mathrm{mg}$ of sodium pentobarbital (Sanofi BV, Division Algin, Maassluis, The Netherlands). The infected thigh muscles were removed and, after weighing, homogenized in $4 \mathrm{ml}$ of PBS. Appropriate dilutions of the homogenate were plated onto diagnostic sensitivity test plates (Oxoid), and the number of colonies was counted after overnight incubation at $37^{\circ} \mathrm{C}$. Results are expressed as the number of CFUs per gram of infected tissue. All negative cultures were assigned the value $100 \mathrm{CFU} / \mathrm{ml}$, the lower limit of detection.

Biodistribution of radiolabeled proteins. The pharmacology of ${ }^{99 \mathrm{~m}}$ Tc-labeled HNP-1 and IgG (as control) in infected mice was assessed using single-photon emission computed tomography (19). Preceding scintigraphy, a subcutaneous injection of $0.2 \mathrm{ml}$ of $0.2 \mathrm{mg}$ diazepam (Valium; Hoffmann-LaRoche, Mijdrecht, The Netherlands) was administered into the mice for muscle relaxation to obtain optimal acquisitions. The mice were placed in supine position on a planar gamma camera (GCA 901A/W2; Toshiba, Tokyo, Japan) with both hind legs spread out and fixed with surgical tape. Continuous whole body acquisitions of the mice for $60 \mathrm{~s}$ during the first hour, and $5 \mathrm{~min}$ images at $4 \mathrm{~h}$ and $24 \mathrm{~h}$ after administration of the tracer, were made with a gamma camera, equipped with a low-energy general purpose parallel-hole collimator. The camera was connected to a computer (GMI-52A; Toshiba), and images of the animals were obtained in a $256 \times 256$ matrix. The energy peak was set at $140 \mathrm{keV}$ with a window of $20 \%$. On the scintigrams of the mice, regions of interest (ROIs) 
Table I. Effect of HNP-1 on Bacterial Outgrowth and Leukocyte Numbers per Lavage in Mice Peritoneally Infected with K. pneumoniae

\begin{tabular}{lcccccc}
\hline & \multicolumn{5}{c}{ Amount of HNP-1 injected } \\
\cline { 2 - 6 } & 0 & $0.4 \mathrm{ng}$ & $4 \mathrm{ng}$ & $40 \mathrm{ng}$ & $400 \mathrm{ng}$ & $4.0 \mu \mathrm{gg}$ \\
\hline Bacterial numbers & $6.5 \pm 5.5 \times 10^{5}$ & $2.4 \pm 3.3 \times 10^{5}$ & $5.4 \pm 11.1 \times 10^{4 *}$ & $8.7 \pm 9.8 \times 10^{3 \ddagger}$ & $2.3 \pm 3.5 \times 10^{3 \ddagger}$ & $6.4 \pm 17.4 \times 10^{3 \ddagger}$ \\
Cell numbers & & & & & \\
Macrophages & $4.7 \pm 0.1 \times 10^{5}$ & $2.2 \pm 0.4 \times 10^{5}$ & $5.9 \pm 5.2 \times 10^{5}$ & $1.3 \pm 1.0 \times 10^{6}$ & $7.2 \pm 5.8 \times 10^{6}$ & $1.2 \pm 0.9 \times 10^{7 *}$ \\
Granulocytes & $4.1 \pm 1.6 \times 10^{5}$ & $3.2 \pm 1.2 \times 10^{6}$ & $3.0 \pm 1.0 \times 10^{6}$ & $1.9 \pm 1.0 \times 10^{6}$ & $5.1 \pm 3.2 \times 10^{6 *}$ & $1.5 \pm 0.4 \times 10^{7 * *}$ \\
Lymphocytes & $2.3 \pm 0.5 \times 10^{5}$ & $9.0 \pm 1.0 \times 10^{5}$ & $1.8 \pm 0.7 \times 10^{6}$ & $9.0 \pm 4.1 \times 10^{5}$ & $2.5 \pm 1.9 \times 10^{6 *}$ & $6.7 \pm 6.7 \times 10^{6 *}$ \\
\hline
\end{tabular}

Values are expressed as CFUs for bacteria or the number of leukocytes per lavage at $24 \mathrm{~h}$ after injection of the peptide. The results are the mean ( \pm SEM) of at least three animals. ${ }^{*} P<0.04,{ }^{\ddagger} P<0.002$ compared with saline controls, according to Mann-Whitney U test.

measuring $5 \mathrm{~mm} \times 5 \mathrm{~mm}$ were drawn over infected (target) and noninfected (nontarget) thighs. The target-to-nontarget ratio of the counts in these ROIs (T/NT ratio) of each mouse was taken as a measure for accumulation of the peptide at sites of infection. The uptake of the peptide by kidneys, liver, urine bladder was determined in anatomically rendered ROIs, drawn over these organs of infected mice. The clearance of the radiolabeled peptides from the circulation was determined from the counts in a ROI $(3 \mathrm{~mm} \times 3 \mathrm{~mm})$ drawn over the heart (20).

Assay of antibacterial and antiviral activity of HNP-1 in vitro. The antibacterial activity of HNP-1, ${ }^{99 \mathrm{~m}}$ Tc-labeled HNP-1, and reduced and alkylated HNP-1 was investigated in a suspension assay using logarithmic-phase K. pneumoniae. Briefly, $0.1 \mathrm{ml}$ of $10 \mathrm{mM}$ Na-PB, $\mathrm{pH} 7.4$, containing $10 \mu \mathrm{g}$ of HNP-1, $10 \mu \mathrm{g}$ of denaturated (reduced/ alkylated) HNP-1, or $10 \mu \mathrm{g}$ of ${ }^{99 \mathrm{~m}} \mathrm{Tc}-\mathrm{HNP}-1$ was added to $0.1 \mathrm{ml}$ of $\mathrm{Na}-\mathrm{PB}$ supplemented with $2 \%$ (vol/vol) tryptic soybean broth (Difco Laboratories, Detroit, MI) containing $2 \times 10^{5}$ of $K$. pneumoniae. At the onset of the incubation and after $2 \mathrm{~h}$ and $3 \mathrm{~h}$ of incubation at $37^{\circ} \mathrm{C}$ in a shaking waterbath, the number of viable bacteria in the samples was determined microbiologically. The outgrowth of bacteria was calculated and compared with the diluent alone. The antiviral activity of native HNP-1 and reduced/alkylated HNP-1 was tested in an assay using Herpes simplex Type I as a target, as described by Daher et al. (11).

Statistical analysis. The Mann-Whitney U test was used to calculate the significance of the difference in effects between HNP-1 and saline injections on bacterial numbers in infected mice. Also, this test was applied to analyze differences between ${ }^{99 \mathrm{~m}}$ Tc-labeled HNP-1 and $\mathrm{IgG}$ in relation to accumulation and biodistribution in mice with an experimental thigh infection. The relation between doses of HNP-1 and leukocyte numbers was assessed using Pearson's correlation test. The level of significance was set at $P<0.05$ (21).

\section{Results}

\section{Peritoneal infections}

Antibacterial activity of HNP-1 in experimental peritoneal infections. The effect of treatment with various doses of HNP-1 on bacterial numbers in the peritoneal infection model was determined $24 \mathrm{~h}$ after the administration of HNP-1. The number of bacteria recovered from the peritoneal cavity from mice treated with doses of HNP-1 ranging from $4 \mathrm{ng}$ to $4 \mu \mathrm{g}$ was statistically significant $(P<0.04)$ lower as compared with bacterial numbers in saline-treated mice (Table I). HNP-1 administration did not affect bacterial numbers in mice rendered leukocytopenic by cyclophosphamide treatment (Table II).

Effect of reduction and alkylation of HNP-1 on its antibacterial activity. The effect of HNP-1 that had been denaturated by reduction and alkylation on peritoneal bacterial numbers was compared with that of native HNP-1 in K. pneumoniaeinfected mice. The results revealed that the number of viable bacteria in the thigh of mice injected with denaturated HNP-1 $\left(2.4 \pm 1.3 \times 10^{5} / \mathrm{g}\right.$ muscle $)$ did not differ from mice injected with saline $\left(6.5 \pm 5.5 \times 10^{5} / \mathrm{g}\right.$ muscle $)$ and was statistically significantly $(P<0.01)$ higher than in mice injected with native HNP-1 $\left(6.4 \pm 1.7 \times 10^{3} / \mathrm{g}\right.$ of muscle $)$. These data indicate that denaturated HNP-1 does not display antimicrobial activity in vivo.

Leukocyte infiltration at sites of infection in HNP-1-treated mice. In $K$. pneumoniae-infected mice, an increase in the number of peritoneal macrophages, granulocytes, and lymphocytes was observed at all time intervals after injection (Fig. 1,

Table II. Effect of HNP-1 on Bacterial Outgrowth and Leukocyte Numbers per Lavage in Leukocytopenic Mice Peritoneally Infected with K. pneumoniae

\begin{tabular}{lcccc}
\hline & \multicolumn{3}{c}{ Amount of HNP-1 injected } \\
\cline { 2 - 5 } & 0 & $40 \mathrm{ng}$ & $400 \mathrm{ng}$ & \multicolumn{2}{c}{$3.3 \pm 4.3 \times 10^{6}$} \\
\hline Bacterial numbers & $2.0 \pm 2.5 \times 10^{6}$ & $1.2 \pm 1.8 \times 10^{6}$ & & \\
Cell numbers & & & $1.4 \pm 0.7 \times 10^{5 *}$ & $3.2 \pm 2.4 \times 10^{5 *}$ \\
Macrophages & $3.1 \pm 0.8 \times 10^{4}$ & $2.2 \pm 0.5 \times 10^{5 *}$ & $1.3 \pm 0.9 \times 10^{3}$ & $4.3 \pm 5.2 \times 10^{3}$ \\
Granulocytes & $7.4 \pm 1.6 \times 10^{3}$ & $2.9 \pm 0.7 \times 10^{3}$ & $2.3 \pm 1.4 \times 10^{4 *}$ & $4.4 \pm 3.8 \times 10^{4 *}$ \\
Lymphocytes & $5.4 \pm 2.0 \times 10^{3}$ & $6.1 \pm 2.3 \times 10^{4 *}$ & & \\
\hline
\end{tabular}

Values are expressed as CFUs for bacteria or the number of leukocytes per lavage at $24 \mathrm{~h}$ after injection of the peptide. The results are the mean $( \pm$ SEM) of at least three animals. $* P<0.04$, compared with saline controls, according to Mann-Whitney $U$ test. 

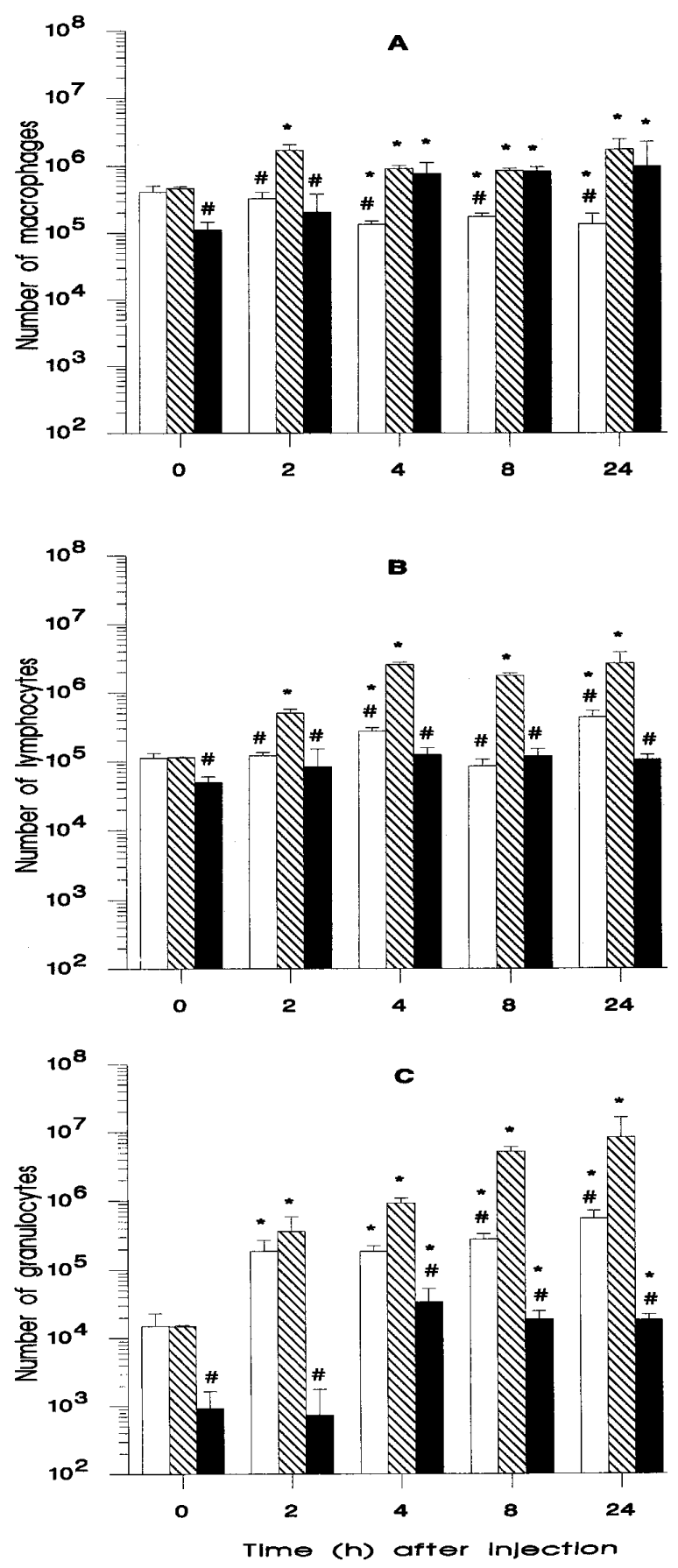

Figure 1. Effect of HNP-1 on the number of leukocytes in the peritoneal cavity of normal and leukocytopenic mice. $(A)$ Effect of HNP-1 on macrophage numbers in the peritoneal cavity of normal (grey bars) and leukocytopenic mice (solid bars). Mice were infected with $10^{6}$ CFUs of K. pneumoniae intraperitoneally, followed 5 min thereafter by an intravenous injection of saline in normal mice (control; open bars) or $0.4 \mu \mathrm{g}$ of ${ }^{99 \mathrm{~m}} \mathrm{Tc}-\mathrm{HNP}-1$. At several time intervals, peritoneal lavage was performed and cell numbers assessed. Each bar represents the mean $( \pm \mathrm{SEM})$ of six animals. $* P<0.03$ compared with $t=0, \# P<0.05$ compared with HNP-1-treated mice. $(B)$ Effect of HNP-1 on lymphocyte numbers in the peritoneal cavity of normal (grey bars) and leukocytopenic mice (solid bars). Mice were infected with $10^{6}$ CFUs of K. pneumoniae intraperitoneally, followed $5 \mathrm{~min}$ thereafter by an intravenous injection of saline in normal mice (control; open bars) or $0.4 \mu \mathrm{g}$ of ${ }^{99 \mathrm{~m} T c-H N P-1 . ~ A t ~ s e v e r a l ~ t i m e ~ i n t e r v a l s, ~}$ peritoneal lavage was performed and cell numbers assessed. Each bar
$A-C)$. The increase $(P<0.04)$ in leukocyte numbers in peritoneal lavage of injected mice was dependent on the dose of HNP-1 administered (Table I) and was not observed with HNP-1 that had been denaturated by reduction and alkylation. HNP-1 also increased leukocyte numbers in leukocytopenic mice (Fig. 1, $A-C$; Table II). However, absolute cell numbers were lower than in HNP-1- or saline-treated normal mice.

\section{Thigh infections}

Next, we assessed the effect of HNP-1 treatment on experimental thigh infections. This model was used to assess the effect of HNP-1 treatment on bacterial numbers and to analyze simultaneously the possible accumulation of ${ }^{99 \mathrm{~m}}$ Tc-labeled HNP-1 in the infected area using scintigraphic techniques.

Antibacterial activity of HNP-1 in experimental thigh infections. Already at $4 \mathrm{~h}$ after administration of $0.4 \mu \mathrm{g}$ of ${ }^{99 \mathrm{~m}} \mathrm{Tc}-$ HNP-1 or native HNP-1, statistically significant $(P<0.01)$ lower numbers of $K$. pneumoniae were recovered from the thighs of mice that had been infected 5 min earlier compared with those from mice injected with saline or ${ }^{99 \mathrm{~m}} \mathrm{Tc}-\operatorname{IgG}$ (Fig. 2). Similar results were observed when the peptide was injected $24 \mathrm{~h}$ after infection, i.e., $5.0 \pm 1.3 \times 10^{4} \mathrm{~K}$. pneumoniae/g of muscle after injection of HNP-1 versus $8.1 \pm 5.9 \times 10^{6} \mathrm{~K}$. pneumoniae/g of muscle after injection of $\mathrm{IgG}$, and $6.7 \pm 3.3 \times 10^{6}$ versus $1.5 \pm 0.4 \times 10^{7} \mathrm{~S}$. aureus/g of muscle, respectively. Furthermore, no differences between the antibacterial effects of ${ }^{99 \mathrm{~m}}$ Tc-labeled and unlabeled HNP-1 were observed, indicating that labeling with ${ }^{99 \mathrm{~m}} \mathrm{Tc}$ did not affect the antibacterial activity of HNP-1. Similar results were found at $24 \mathrm{~h}$ after injection of HNP-1, although for each group the bacterial numbers were higher at $24 \mathrm{~h}$ compared with the number at the 4-h interval. No significant differences between bacterial numbers in mice treated with ${ }^{99 \mathrm{~m}} \mathrm{Tc}-\mathrm{IgG}$ and saline were observed. In accordance with the results of the $K$. pneumoniae infection, also in $S$. aureus-infected mice a statistically significant $(P<0.01)$ lower number of bacteria in mice after injection of ${ }^{99 \mathrm{~m}} \mathrm{Tc}-$ HNP-1 was observed (Fig. 3).

Biodistribution of ${ }^{99 m}$ Tc-labeled HNP-1 in bacterially infected mice. To study the pharmacology of HNP-1 in vivo, ${ }^{99 \mathrm{~m}}$ Tc-labeled HNP-1 was injected in bacterially infected mice. Single-view whole body scintigrams were made with a gamma camera. On the scintigrams, ROIs were drawn, enabling the recording of the radioactivity in organs, such as heart, liver, kidneys, and bladder, and in infected areas at various time intervals. The results revealed that ${ }^{99 \mathrm{~m}} \mathrm{Tc}-\mathrm{HNP}-1$ and ${ }^{99 \mathrm{~m}} \mathrm{Tc}-\mathrm{IgG}$ were rapidly removed from the circulation by the kidneys, and subsequently the bladder, followed by excretion via urine. In K. pneumoniae- and S. aureus-infected mice, the clearance of ${ }^{99 m}$ Tc-HNP-1 from the circulation, determined by calculating radioactivity in ROI drawn over the heart, is statistically signif-

represents the mean $( \pm$ SEM $)$ of six animals. $* P<0.03$ compared with $t=0, \# P<0.05$ compared with HNP-1-treated mice. $(C)$ Effect of HNP-1 on granulocyte numbers in the peritoneal cavity of normal (grey bars) and leukocytopenic mice (solid bars). Mice were infected with $10^{6} \mathrm{CFUs}$ of $K$. pneumoniae intraperitoneally, followed $5 \mathrm{~min}$ thereafter by an intravenous injection of saline in normal mice (control; open bars) or $0.4 \mu \mathrm{g}$ of ${ }^{99 \mathrm{~m}} \mathrm{Tc}-\mathrm{HNP}-1$. At several time intervals, peritoneal lavage was performed and cell numbers assessed. Each bar represents the mean $( \pm$ SEM) of six animals. $* P<0.03$ compared with $t=0, \# P<0.05$ compared with HNP-1-treated mice. 


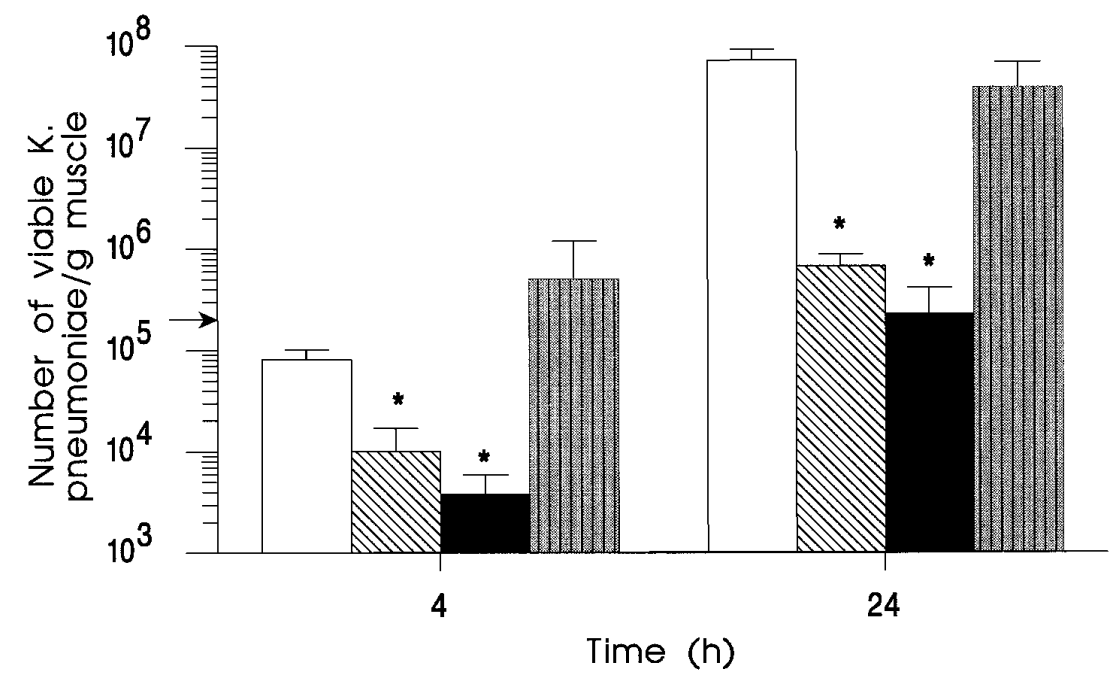

Figure 2. Bacterial numbers in K. pneumoniaeinfected thighs of mice at two intervals after administration of $10 \mu \mathrm{g}$ of ${ }^{99 \mathrm{~m}} \mathrm{Tc}-\mathrm{IgG}$ (open bars) or 0.4 $\mu \mathrm{g}$ of ${ }^{99 \mathrm{~m}} \mathrm{Tc}$-labeled HNP-1 (grey bars), unlabeled HNP-1 (closed bars), or saline (dark grey bars). Results are mean ( \pm SEM) of at least nine animals in three experiments, expressed as CFUs recovered per gram of infected muscle. The arrow on the $y$ axis indicates the number of bacteria administered. ${ }^{*} P<0.01$ compared with ${ }^{99 \mathrm{~m}} \mathrm{Tc}-\mathrm{IgG}$ and saline. icant $(P<0.05)$ faster compared with that of ${ }^{99 \mathrm{~m}} \mathrm{Tc}-\mathrm{IgG}\left(t_{1 / 2}\right.$ amounted to 7-8 min and 24-26 min, respectively).

Already $1 \mathrm{~min}$ after injection, ${ }^{99 \mathrm{~m}} \mathrm{Tc}-\mathrm{HNP}-1$ accumulated at sites of bacterial infections, as was determined by calculation of the T/NT ratio from the scintigram. With ${ }^{99 \mathrm{~m}} \mathrm{Tc}-\mathrm{IgG}$, no nfection was detectable until 15 min postinjection. During the first $15 \mathrm{~min}$ after injection, we observed in both K. pneumoniae - and $S$. aureus-infected mice a statistically significant $(P<0.05)$ higher T/NT ratio of ${ }^{99 \mathrm{~m}}$ Tc-HNP-1 compared with that for ${ }^{99 \mathrm{~m}} \mathrm{Tc}-\mathrm{IgG}$ (Figs. 4 and 5). In contrast to HNP-1, the T/NT ratios for ${ }^{99 \mathrm{~m}} \mathrm{Tc}-\mathrm{IgG}$ increased $(P<0.05)$ during the course of the infection; the T/NT ratios of ${ }^{99 m}$ Tc-IgG at the $24 \mathrm{~h}$ interval of the experiment in both $K$. pneumoniae- and $S$. aureus-infected mice were statistically significant $(P<$ 0.05 ) higher compared with the corresponding T/NT ratios of 99m Tc- HNP-1.

Antibacterial and antiviral activity of labeled and denaturated $H N P-1$ in vitro

The effect of the labeling procedure on the antibacterial activity of HNP-1 against $K$. pneumoniae was determined in vitro. At $50 \mu \mathrm{g} / \mathrm{ml}$, both HNP-1 and ${ }^{99 \mathrm{~m}}$ Tc-labeled HNP-1 were equally bactericidal toward $K$. pneumoniae; at $2 \mathrm{~h}$ and $3 \mathrm{~h}$ of incubation no viable bacteria were detectable by colony counting.

In addition, the effect of reduction and alkylation of HNP-1 on the in vitro antibacterial and antiviral activity was assessed. HNP-1 denaturated by reduction and alkylation displayed a marked reduced antibacterial activity against $K$. pneumoniae in vitro. Denaturated HNP-1 caused a minor (11\%) reduction in bacterial numbers, whereas upon incubation with native HNP-1 no residual viable bacteria were observed as determined by colony counting. Similar results were observed in additional experiments in which we studied the effect of reduction and alkylation of HNP-1 on the antiviral activity of HNP-1 in an assay using Herpes simplex Type I as target. The results revealed that denaturated HNP-1 in contrast to native HNP-1 did not display antiviral activity.

\section{Discussion}

The main conclusion from this study is that administration of HNP-1 results in a marked decrease in bacterial numbers in

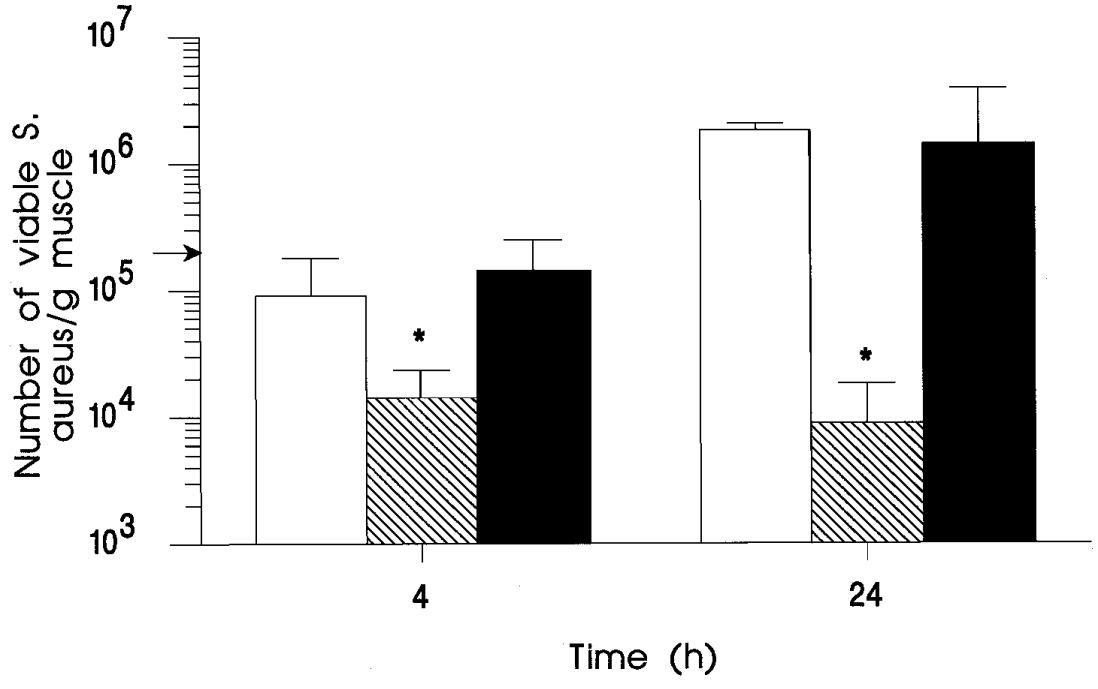

Figure 3. Bacterial numbers in S. aureus-infected thighs of mice at two intervals after administration of $10 \mu \mathrm{g}$ of ${ }^{99 \mathrm{~m}} \mathrm{Tc}-\mathrm{IgG}$ (open bars) or $0.4 \mu \mathrm{g}$ of HNP-1 (grey bars) or saline (closed bars). Results are mean $( \pm$ SEM $)$ of at least nine animals in three experiments, expressed as CFUs recovered per gram of infected muscle. The arrow on the $y$ axis indicates the number of bacteria administered. $* P<0.01$ compared with ${ }^{99 \mathrm{~m}} \mathrm{Tc}-\mathrm{IgG}$ and saline. 


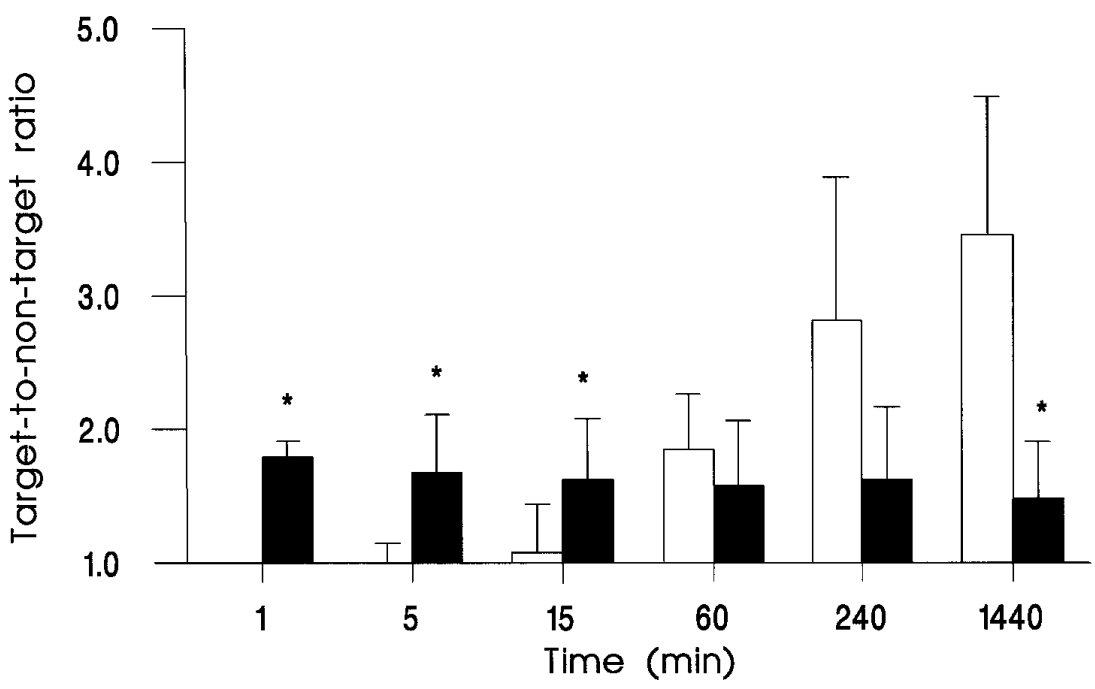

Figure 4. T/NT ratios of a $K$. pneumoniae thigh infection with ${ }^{99 \mathrm{~m}} \mathrm{Tc}-\mathrm{HNP}-1$ (closed bars) or ${ }^{99 \mathrm{~m}} \mathrm{Tc}-$ $\mathrm{IgG}$ (open bars) at various intervals after the administration of the tracer. Each symbol represents the mean value $( \pm$ SEM $)$ of at least nine animals. ${ }^{*} P<0.05$, compared with ${ }^{99 \mathrm{~m}} \mathrm{Tc}-\mathrm{IgG}$. experimental infections in mice. This activity is associated with local phagocyte and lymphocyte accumulation, which appears to be essential for the observed antibacterial effect with HNP-1 as determined in leukocytopenic mice. Originally, the present studies were initiated to investigate the ability of ${ }^{99 \mathrm{~m}}$ Tc-HNP-1 and ${ }^{99 m} \mathrm{Tc}-\mathrm{IgG}$ to localize experimental infections in mice (Welling et al., manuscript in preparation). During the course of these studies, we noted marked differences between HNP-1and saline- or IgG-treated mice. Whereas the bacterial infection caused marked changes in the behavior and appearance in control or IgG-treated mice, this was much less apparent in HNP-1-treated animals. This prompted us to investigate the effect of HNP-1 treatment on bacterial numbers.

We considered the possibility that contaminants in the HNP-1 preparation caused the observed effects of HNP-1 on bacterial and leukocyte numbers. It is unlikely that contaminating traces of LPS in the HNP-1 preparation could explain our findings because LPS content was found to be $<100$ $\mathrm{pg} / \mathrm{ml}$, far below concentrations needed for LPS to induce chemokine synthesis $(22,23)$. In addition, control experiments using HNP-1 that had been denaturated by reduction and alkylation were performed. We observed that the in vitro anti- viral and antibacterial activity of HNP-1 was completely abrogated by reduction and alkylation, as was also described by others (11). In addition, upon reduction and alkylation, HNP-1 lost its antibacterial activity in vitro. Also in vivo, reduced and alkylated HNP-1 did not affect bacterial or leukocyte numbers in experimental peritoneal $K$. pneumoniae infections. These results indicate that the integrity of the disulphide bonds in HNP-1 is required for its in vitro and in vivo antibacterial activities and argue against contaminants in the HNP-1 preparation as being the active substances mediating the marked effects of HNP-1 in vivo.

What are the possible mechanisms involved in the in vivo antibacterial activity of HNP-1 in experimental infections in mice? First, in view of the very small amounts of HNP-1 injected, it is extremely unlikely that the observed effects can be explained by a direct antibacterial effect of injected HNP-1. Our observation that HNP-1 treatment increases local leukocyte accumulation at the site of infection and the absence of an antibacterial effect of HNP-1 treatment in leukocytopenic mice suggests that leukocytes that have been recruited as a result of HNP-1 treatment eradicate the local infection. In agreement with this view, we found that the increase in leukocyte

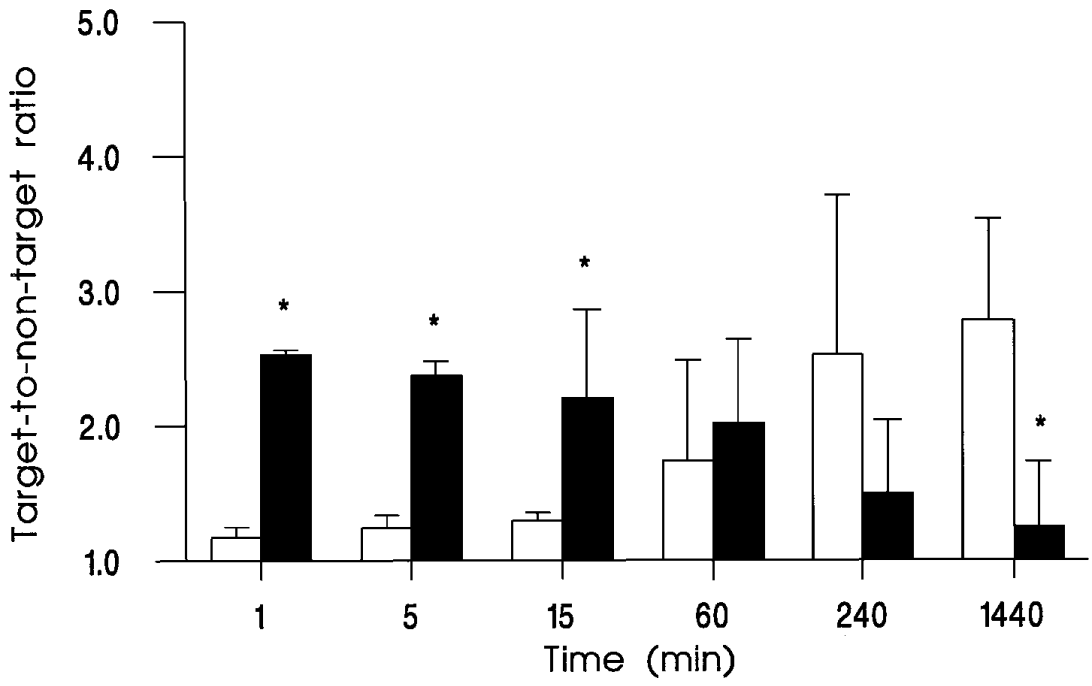

Figure 5. T/NT ratios of a $S$. aureus thigh infection with ${ }^{99 \mathrm{~m}} \mathrm{Tc}$-HNP-1 (closed bars) or ${ }^{99 \mathrm{~m}} \mathrm{Tc}-\mathrm{IgG}$ (open bars) at various intervals after the administration. Each symbol represents the mean value ( \pm SEM) of at least six animals. $* P<0.05$, compared with ${ }^{99 \mathrm{~m}} \mathrm{Tc}-\mathrm{IgG}$. 
numbers in cyclophosphamide-treated mice after administration of HNP-1 was statistically significant $(P<0.01)$ though smaller than in control mice, and therefore this influx may have been insufficient. Recently, we found that different (synthetic) antimicrobial peptides also display both antimicrobial and chemotactic effects in infected mice, indicating that these effects in mice are not restricted to HNP-1. Furthermore, our present results for HNP-1 are in line with the observation by Chertov et al. (6), demonstrating that a subcutaneous injection of $1 \mu \mathrm{g}$ of HNP-1 results in accumulation of neutrophils and mononuclear cells. In addition, this hypothesis is supported by reports on the in vitro chemotactic activity of neutrophil defensins for lymphocytes and monocytes $(5,6)$, and the capacity of high concentrations $(100 \mu \mathrm{g} / \mathrm{ml})$ to induce IL- 8 secretion from epithelial cells (7). Activation of accumulated neutrophils by HNP-1 is another possible explanation, but in vitro studies demonstrate that neutrophil defensins decrease phagocytosis and the associated production of reactive oxygen intermediates (24). We cannot exclude the possibility that the opsonic activity of neutrophil defensins (25) contributes to the observed in vivo antibacterial activity. It has to be noted that all these reported effects of neutrophil defensins were noted with higher concentrations than those that are expected to be found locally in mice injected with the amounts of HNP-1 used in the present study.

In our experiments, we used human neutrophil defensins in murine infection models. Murine neutrophils, in contrast to those of other rodents, do not contain defensins (26). Mice are not devoid of defensins, since murine Paneth cells contain cryptdins, which, like neutrophil defensins, belong to the subfamily of $\alpha$-defensins (4). In addition, recently the first murine $\beta$-defensin was identified (27). The use of human neutrophil defensins in mice may in part explain why the extremely small amounts of injected HNP-1 cause the marked effects observed in the present study. It was previously reported that subcutaneous injection of $1 \mu \mathrm{g}$ of HNP-1 in mice results in local leukocyte accumulation (6). The effects observed in the present study were already achieved with doses of HNP-1 below $1 \mu \mathrm{g}$. We cannot exclude the possibility that human neutrophil defensins are particularly active in activating mouse endogenous defense systems, whereas their activity in homologous systems may be much less pronounced. This is an important consideration in view of reports demonstrating that in sepsis and various infections in humans, neutrophil defensins reach plasma levels that by far exceed those expected to be found in the murine circulation of HNP-1-injected animals in the present study $(28,29)$.

Finally, we determined the use of ${ }^{99 \mathrm{~m}} \mathrm{Tc}$-labeled HNP-1 as an infection-seeking tracer. In the thigh infection model, it was demonstrated that shortly after injection, ${ }^{99 \mathrm{~m}}$ Tc-labeled HNP-1 accumulates in infected areas. Compared with ${ }^{99 \mathrm{~m}} \mathrm{Tc}$-labeled $\mathrm{IgG}$, lower T/NT values as observed at intervals from $4 \mathrm{~h}$ on might be explained by the reduction in bacterial number induced by HNP-1, because an increase in the accumulation of $\mathrm{IgG}$ is related to the outgrowth of bacteria present at the site of infection (9). The difference in molecular size between HNP-1 (mol wt $=3500)$ and $\mathrm{IgG}(\mathrm{mol} \mathrm{wt}=150,000)$ is a plausible explanation for enabling small molecules to get easier access to infected sites (15).

In summary, HNP-1 displays a marked antibacterial activity in experimental infections in mice. This activity is associated with local leukocyte accumulation, which appears to be essential for the antibacterial activity due to the absence of that effect in leukocytopenic mice. In addition, the accumulation of ${ }^{99 \mathrm{~m}}$ Tc-labeled HNP-1 at the site of infection may be of potential use to localize bacterial infections.

\section{Acknowledgments}

We are indebted to Dr. Emile de Heer and Annemiek van de Wal of the Department of Pathology for their helpful discussions, Timo Zomerdijk of the Department of Infectious Diseases for performing the antiviral assay, and Sandra van Wetering of the Department of Pulmonology for the purification of HNP-1. The technical assistance of Petra Dibbets-Schneider and Bram Sinon of the Department of Radiology, Division of Nuclear Medicine, is appreciated.

\section{References}

1. Hancock, R.E.W. 1997. Peptide antibiotics. Lancet. 349:418-422.

2. Ganz, T., M.E. Selsted, D. Szklarek, S.S. Harwig, K. Daher, D.F. Bainton, and R.I. Lehrer. 1985. Defensins. Natural peptide antibiotics of human neutrophils. J. Clin. Invest. 76:1427-1435.

3. Lehrer, R.I., A. Barton, K.A. Daher, S.S. Harwig, T. Ganz, and M.E. Selsted. 1989. Interaction of human defensins with Escherichia coli. Mechanism of bactericidal activity. J. Clin. Invest. 84:553-561.

4. Lehrer, R.I., A.K. Lichtenstein, and T. Ganz. 1993. Defensins: antimicrobial and cytotoxic peptides of mammalian cells. Annu. Rev. Immunol. 11:105128 .

5. Territo, M.C., T. Ganz, M.E. Selsted, and R. Lehrer. 1989. Monocytechemotactic activity of defensins from human neutrophils. J. Clin. Invest. 84: 2017-2020.

6. Chertov, O., D.F. Michiel, L. Xu, J.M. Wang, K. Tani, W.J. Murphy, D.L. Longo, D.D. Taub, and J.J. Oppenheim. 1996. Identification of defensin-1, defensin-2, and CAP37/azurocidin as T-cell chemoattractant proteins released from interleukin-8-stimulated neutrophils. J. Biol. Chem. 271:2935-2940.

7. van Wetering, S., S.P.G. Mannesse-Lazeroms, M.A.J.A. van Sterkenburg, M.R. Daha, J.H. Dijkman, and P.S. Hiemstra. 1997. Effects of defensins on IL-8 synthesis in airway epithelial cells. Am. J. Physiol. 272:888-896.

8. van Waarde, D., E. Hulsing-Hesselink, L.A. Sandkuyl, and R. van Furth 1977. Humoral regulation of monocytopoiesis during the early phase of an inflammatory reaction caused by particulate substances. Blood. 50:141-154.

9. Calame, W., R.I.J. Feitsma, G.J. Ensing, W.J. Goedemans, J.A.J. Camps, R. van Furth, and E.K.J. Pauwels. 1991. Detection of a local staphylococcal infection in mice with ${ }^{99 \mathrm{~m}} \mathrm{Tc}-$ labelled polyclonal human immunoglobulin. J. Nucl. Med. 32:468-474.

10. Calame, W., R.I.J. Feitsma, G.J. Ensing, R. Van Furth, and E.K.J. Pauwels. 1991. Binding of ${ }^{99 \mathrm{~m}}$ Tc-labelled polyclonal human immunoglobulin to bacteria as a mechanism for scintigraphic detection of infection. Eur. J. Nucl. Med. 18:396-400.

11. Daher, K.A., M.E. Selsted, and R.I. Lehrer. 1986. Direct inactivation of viruses by human granulocyte defensins. J. Virol. 60:1068-1074.

12. Pauwels, E.K.J., M.M. Welling, R.I.J. Feitsma, D.E. Atsma, and W. Nieuwenhuizen. 1993. The labeling of proteins and LDL with ${ }^{99 \mathrm{~m}} \mathrm{Tc}$ : a new direct method employing $\mathrm{KBH}_{4}$ and stannous chloride. Nucl. Med. Biol. 20:825833.

13. Stolk, J., J. Camps, R.I.J. Feitsma, R. Maassen, J. Hermans, J.H. Dijkman, and E.K.J. Pauwels. 1995. Pulmonary deposition and disappearance of aerosolized secretory leucocyte protease inhibitor. Thorax. 50:645-650.

14. Calame, W., R.I.J. Feitsma, and E.K.J. Pauwels. 1992. Scintigraphic detection of inflammatory disease by various radiopharmaceuticals, especially labelled immunoglobulin. In Nuclear Medicine in Research and Practice, Vol. 28. FK Schattauer Verlag GmbH, Stuttgart, Germany. 260-269.

15. Becker, W. 1995. The contribution of nuclear medicine to the patient with infection. Eur. J. Nucl. Med. 22:1195-1211.

16. Calame, W., M.M. Welling, R.I.J. Feitsma, W.T. Goedemans, and E.K.J. Pauwels. 1995. Contribution of phagocytic cells and bacteria to the accumulation of technetium-99m labelled polyclonal human immunoglobulin at sites of inflammation. Eur. J. Nucl. Med. 22:638-644.

17. Gerber, A.U., H.P. Brugger, C. Feller, T. Stritzko, and B. Stalder. 1986. Antibiotic therapy of infections due to Pseudomonas auruginosa in normal and granulocytopenic mice: comparison of murine and human pharmacokinetics. $J$. Infect. Dis. 153:90-97.

18. Kunst, M.W., and H. Mattie. 1978. Cefazolin and cephradine: relationship between antibacterial activity in vitro and in mice experimentally infected with Escherichia coli. J. Infect. Dis. 137:391-402.

19. Lambrecht, R.M. 1996. Biological models in radiopharmaceutical development, 1st ed. In Developments in Nuclear Medicine, Vol. 27. P.H. Cox, editor. Kluwer Academic Publishers, Dordrecht, The Netherlands. 
20. Welling, M.M. 1997. Localization of bacterial infections with ${ }^{99 m}$ Technetium-labeled tracers: an optimization study. Ph.D. thesis. University of Leiden, Leiden, The Netherlands. Shaker Publishing bv. Maastricht, The Netherlands.

21. Snedecor, G.W., and W.G. Cochran. 1980. Statistical Methods, 7th ed. The Iowa State University Press, Ames, IA.

22. Polman, T.H., K.A. Stanness, and P.G. Beatty. 1986. An endothelial cell surface factor induced in vitro by LPS, IL-1 and TNF increases neutrophil adherence by a CDw 18-dependent mechanism. J. Immunol. 136:4548-4553.

23. Deakin, A.M., A.N. Payne, and B.J.R. Whittle. 1995. The modulation of IL- 6 and TNF- $\alpha$ releases by nitric oxide following stimulation of J774 cells with LPS and IFN- $\gamma$. Cytokine. 7:408-416.

24. Nakajima, Y., J. Alvarez-Bravo, J.H. Cho, K. Homma, S. Kanegasaki, and S. Natori. 1997. Chemotherapeutic activity of synthetic antimicrobial peptides: correlation between chemotherapeutic activity and neutrophil activating activity. FEBS Lett. 415:64-66.

25. Ganz, T., M.E. Selsted, and R.I. Lehrer. 1990. Defensins. Eur. J. Haematol. 44:1-8.

26. Eisenhauer, P.B., and R.I. Lehrer. 1992. Mouse neutrophils lack defensins. Infect. Immun. 60:3446-3447.

27. Bals, R., M.J. Goldman, and J.M. Wilson. 1998. Mouse $\beta$-defensin 1 is a salt-sensitive antimicrobial peptide present in epithelia of the lung and urogenital tract. Infect. Immun. 66:1225-1232.

28. Panyutich, A.V., E.A. Panyutich, V.A. Krapivin, E.A. Baturevich, and T. Ganz. 1993. Plasma defensin concentrations are elevated in patients with septicemia or bacterial meningitis. J. Lab. Clin. Med. 122:202-207.

29. Ihi, T., M. Nakazato, H. Mukae, and S. Matsukura. 1997. Elevated concentrations of human neutrophil peptides in plasma, blood, and body fluids from patients with infections. Clin. Infect. Dis. 25:1134-1140. 